\title{
Nature and genesis of Kalimantan diamonds
}

\author{
Chris B. Smith ${ }^{1}$, Galina P. Bulanova ${ }^{2}$, H. Judith Milledge ${ }^{3}$, Anne E. Hall ${ }^{4}$, Brendan J. \\ Griffin $^{5}$, and D. Graham Pearson ${ }^{6}$ \\ ${ }^{1}$ Rio Tinto Mining and Exploration Pty. Ltd., London, UK, \\ ${ }^{2}$ University of Bristol, U.K, \\ ${ }^{3}$ University College, London UK \\ ${ }^{4}$ Canberra, Australia, \\ ${ }^{5}$ University of Western Australia, Australia, \\ ${ }^{6}$ University of Durham, UK.
}

\begin{abstract}
Introduction
Occurrences of alluvial diamonds located within relatively young geological terrains without obvious primary source are found in the Urals, California, Eastern Australia, Kalimantan, Burma (Myanmar) and Thailand. It is controversial whether such diamonds formed in conventional ancient lithospheric mantle or in a Phanerozoic subducted slab perhaps subsequently obducted to surface. The aim of this study is to constrain the origin of Kalimantan diamonds through characterisation of their properties, determination of PT and age of formation. Almost one thousand diamonds were studied from 4 localities (west, central, south, Kelian) across the island of Kalimantan.
\end{abstract}

\section{Geological setting}

Diamond production from Kalimantan ("Diamond River") has been entirely from Quaternary to Recent alluvials since ancient times $(\sim 600 \mathrm{AD}$, Webster (1983)). No primary igneous host rock has been identified. Kalimantan lies in a young arc setting, to the north of the Java Trench, formed during the convergence of the Indo-Australian, Eurasian and western Pacific microplates from Mesozoic times onwards (Parkinson et al., 1998).

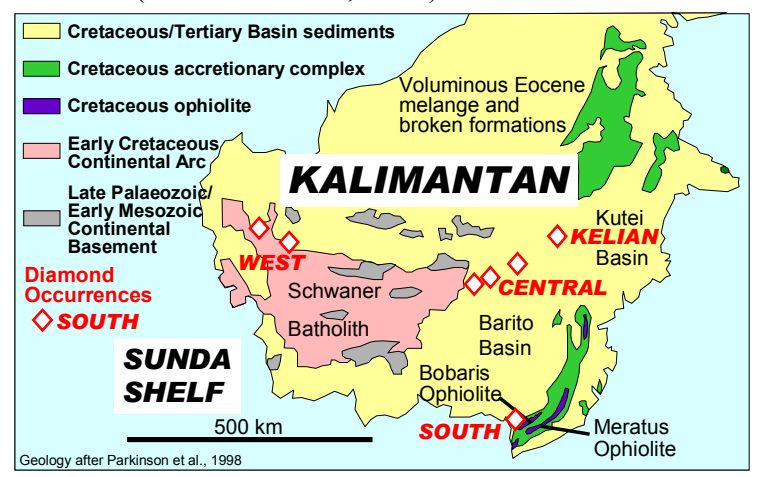

Fig. 1. Location of studied Kalimantan diamonds.

The oldest basement recognised on Kalimantan consists of late Palaeozoic/early Mesozoic volcaniclastics and marine sediments intruded by the
Cretaceous Schwaner granitic batholith (Fig. 1). One can only speculate on the chances of such basement being underlain by a fragment of ancient diamondiferous lithosphere torn off a Gondwanaland continental fragment.

Cretaceous accretionary complexes (?metamorphism at $\mathrm{P}=1.8 \mathrm{GPa}$, Parkinson et al., op. cit.) and ophiolite with associated garnet pyroxenite occur in east Kalimantan. Garnet peridotite and garnet pyroxenite has been found in association with the East Sulawesi Ophiolite on the neighbouring island of Sulawesi and has yielded peak metamorphism conditions of $2.8 \mathrm{GPa}$ at $1030-1100^{\circ} \mathrm{C}$ (Parkinson et al., op. cit.). Could such obducted ophiolites be the source of Kalimantan diamonds?

\section{Diamond morphology}

872 stones (39 from West Kalimantan, 73 from Central, 106 from Kelian and 654 from South Kalimantan) were examined under the binocular microscope and described for shape, colour, inclusion content, internal defects, surface etchings and features, and evidence of abrasion during travel.

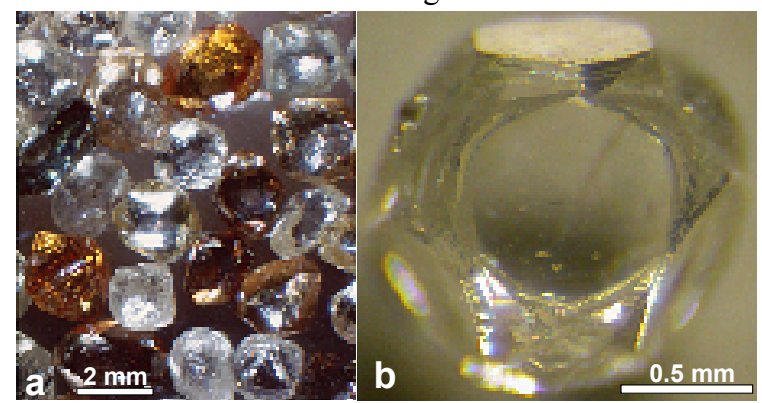

Fig. 2. (a) Stones from South Kalimantan, and (b) an unusual "diver's helmet" octahedral form from Kelian.

Kalimantan stones are generally colourless, pale brown or pale yellow, shiny surfaced, intensively resorbed, dodecahedroids, transitional forms (Fig. 2a) and more rarely cube combination forms. The stones have common surface radiation damage, $42 \%$ showing brown radiation spots indicative of exposure to alpha 
particle damage and temperatures of at least $550-600^{\circ} \mathrm{C}$ (Vance et al., 1973), suggestive of deep burial probably in a sedimentary package. The stones are of high gem quality, although small in size, and there is a notable absence of broken crystals or cleaved forms, such as characterise primary kimberlite production or proximity to pipe source. Surprisingly, wear features such as rhombic cracks and fretted edges indicative of substantial abrasive transportation make up only $8 \%$ of the population, perhaps reflecting the smooth, rounded, less easily abraided shapes of the stones. Each region of Kalimantan yielded stones that were similar morphologically, the one exception being a somewhat larger, but still minor, proportion of unusual "diver's helmet" shapes at Kelian (Fig. 2b). The implication of the morphological study was that the stones had been transported from their primary source or sources, mixed, buried and recycled into the modern alluvials.

\section{Diamond internal structure and nitrogen aggregation}

Thirty two diamonds were polished down to expose mineral inclusions and reveal their internal structure by cathodoluminescence (CL) imaging, and were investigated by FTIR to determine their nitrogen aggregation characteristics. 149 other stones were examined as whole crystals by CL and FTIR. $80 \%$ of the diamonds are homogeneous or have simple octahedral zonation and show high degrees of resorption and plastic deformation (Fig. 3a).

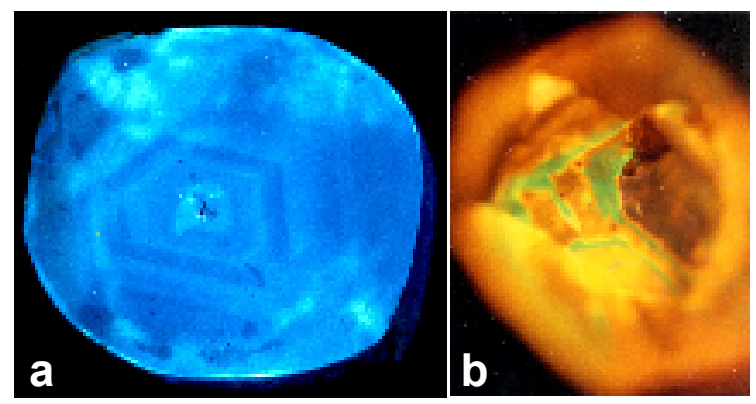

Fig. 3. (a) CL image of South Kalimantan diamond with simple octahedral growth zonation followed by resorption; (b) Kelian diamond showing a thin skin of Type Ib (orange CL) over Type Ia interior (blue CL).

A rare group of stones have amber colour and orange CL (Fig. 3b) reflecting a thin outer skin of type Ib diamond, possibly implying late skin growth just prior to crustal emplacement.

FTIR measurements showed a range of $\mathrm{N}$ aggegation characteristics from Type II through weakly aggregated IaA to well-aggregated type IaB. The strongly aggregated stones imply likely long term growth and/or high temperatures. As an illustration, diamond DK15 from South Kalimantan, dated at 3.1 Ga (see below), has $\mathrm{N}$ concentrations of 529-573 ppm and aggregation of $33-41 \% \mathrm{IaB}$ - these values for DK15, using experimentally-determined time, temperature, and $\mathrm{N}$ aggregation relationships, imply temperatures of 1110 $1117^{\circ} \mathrm{C}$ which are quite typical for diamond formation in the lithospheric mantle. DK15 carries olivine and orthopyroxene inclusions. Applying an average temperature of $1114^{\circ} \mathrm{C}$ for DK15 to the Al-in-opx barometer of Brey and Kohler (1990) would realise a pressure of $54.4 \mathrm{Gpa}$ and locate the diamond on a $40 \mathrm{~mW} / \mathrm{m} 2$ geotherm typical of subcontinental cratonic lithosphere.

Combining the distinctive diamond morphologies with the $\mathrm{CL}$ and nitrogen abundance and aggregation characteristics, five main diamond populations can be recognised in Kalimantan (Table 1).

Table 1. Kalimantan diamond populations

\begin{tabular}{|l|l|l|}
\hline Group Name & Characteristics & Implications \\
\hline $\begin{array}{l}\text { Cube } \\
\text { combination } \\
\text { forms }\end{array}$ & $\begin{array}{l}\text { Cube features, low N, low H, } \\
\text { low aggregration (II or IaA), } \\
\text { platelets absent }\end{array}$ & Fast growth \\
\hline Amber type Ib & $\begin{array}{l}\text { Distinctive amber or strong } \\
\text { yellow natural colour; bright } \\
\text { orange CL caused by a thin } \\
\text { skin of type Ib }\end{array}$ & $\begin{array}{l}\text { Late of } \\
\text { growth } \\
\text { unaggregated, } \\
\text { single } \\
\text { substitional } \\
\text { nitrogen }\end{array}$ \\
\hline Browns & $\begin{array}{l}\text { Brown colour, medium N, } \\
\text { strong aggregation (IaA,IaB; } \\
\text { occasional IaB); modest to } \\
\text { high platelet development }\end{array}$ & $\begin{array}{l}\text { Long mantle } \\
\text { residence } \\
\text { and/or high } \\
\text { temperature }\end{array}$ \\
\hline Yellows & $\begin{array}{l}\text { Yellow colour, high N but } \\
\text { moderate aggregation } \\
\text { (IaA>IaB); variable platelet } \\
\text { development }\end{array}$ & $\begin{array}{l}\text { Moderate } \\
\text { mantle } \\
\text { residence time } \\
\text { and/or cooler } \\
\text { temperature } \\
\text { than browns }\end{array}$ \\
\hline $\begin{array}{l}\text { Diver's } \\
\text { Helmets }\end{array}$ & $\begin{array}{l}\text { Distinctive morphology; } \\
\text { otherwise similar to yellows }\end{array}$ & \multicolumn{2}{|c|}{} \\
\hline
\end{tabular}

All of these populations occur in every diamond region of Kalimantan, excepting the cube combination forms which make up about $5 \%$ of the Kelian and South Kalimantan populations but have not been seen in the Central or West Regions. The yellow and brown populations are the dominant types and relatively equal in abundance.

\section{Inclusions}

Inclusions from the "Browns" population (Table 1) were analysed in situ by electron microprobe (Table 2). Inclusion parageneses are $60 \%$ peridotitic and $40 \%$ eclogitic. Peridotitic inclusions are represented by olivine, chromite, garnet, orthopyroxene and pentlandite. Olivines have Fo 92-93 and belong to the dunite-harzburgite paragenesis, with one at Fo 90 classified as lherzolitic.

Chromites have 65-66 wt.\% $\mathrm{Cr}_{2} \mathrm{O}_{3}$ and $\mathrm{TiO}_{2}<1$ wt. \% typical of world wide diamond inclusion chromites derived from cratons.

Garnet inclusions are subcalcic high chrome harzburgite "G10s", with one mildly subcalcic, transitional between "G9" and "G10" (Fig. 4). This latter garnet coexists with olivine of lherzolitic affinity (Fo 90) in the same diamond. Eclogitic inclusions are represented by omphacite, rutile, kyanite and coesite. Coexisting chromite-olivine inclusions found within 
the diamond gave a formation temperature of $1087^{\circ} \mathrm{C}$, assuming constant pressure of $50 \mathrm{~kb}$ (O'Neill and Wall, 1987).

Table 2. Representative EMP analysis of inclusions from Kalimantan diamonds.

\begin{tabular}{|c|c|c|c|c|c|c|c|c|c|c|}
\hline Loc: & $\begin{array}{r}\mathrm{W} \\
\mathrm{Kal} \\
\end{array}$ & $\begin{array}{r}\mathrm{S} \\
\mathrm{Kal} \\
\end{array}$ & $\begin{array}{r}\mathrm{W} \\
\mathrm{Kal}\end{array}$ & $\begin{array}{r}\text { W. } \\
\text { Kal } \\
\end{array}$ & $\begin{array}{r}\mathrm{S} \\
\mathrm{Kal} \\
\end{array}$ & $\begin{array}{r}\mathrm{S} \\
\mathrm{Kal} \\
\end{array}$ & $\begin{array}{r}\mathrm{W} \\
\mathrm{Kal}\end{array}$ & $\begin{array}{r}\mathrm{S} \\
\mathrm{Kal} \\
\end{array}$ & $\begin{array}{r}\text { W. } \\
\text { Kal }\end{array}$ & $\mathrm{Kal}$ \\
\hline & DK4 & $\begin{array}{c}\text { Cem } \\
9-9 \\
\end{array}$ & DK5 & $\begin{array}{c}\text { DK2 } \\
5 \\
\end{array}$ & Mat 1 & $\begin{array}{c}\text { Cem } \\
9-9\end{array}$ & \begin{tabular}{|c|} 
DK1 \\
5 \\
\end{tabular} & $\begin{array}{c}\text { Cem. } \\
9-7\end{array}$ & DK34 & Mat. 4 \\
\hline & & $\mathrm{Ol}$ & $\mathrm{Gt}$ & $\mathrm{Gt}$ & Chr & Chr & Opx & Opx & Omph & Omph \\
\hline $\mathrm{SiO}_{2}$ & 42.1 & 41.5 & 41.99 & 41.3 & & & 59.2 & 57.64 & 55.37 & 56.01 \\
\hline & 0 & 0 & 0 & 0 & 0.14 & 0.18 & 0 & 0.03 & 0 & \\
\hline & 0 & 0 & 17.15 & 16 & 5.34 & 4.98 & 0.77 & 0.88 & 8.19 & 3.19 \\
\hline & 0 & 0 & 9.03 & 9.97 & 64.97 & 66.3 & 0.53 & 0.42 & 0 & 0.16 \\
\hline & 6.3 & 6.67 & 6.47 & 8.36 & 16.86 & 14.8 & 4.49 & 4.06 & 3.09 & 6.93 \\
\hline & 0 & 0 & 0.28 & 0.24 & 0 & 0 & 0 & 0.08 & 0 & \\
\hline & 50.4 & 50.1 & 21.48 & 19 & 12.15 & 13 & 34.3 & 35.30 & 12.36 & 16.35 \\
\hline & 0.27 & 0.29 & & & 0.24 & 0 & & 0.15 & & \\
\hline & 0.2 & 0 & 3.8 & 5.5 & & & 1.03 & 0.68 & 18.36 & 15.22 \\
\hline & 0 & 0 & 0 & 0 & & & 0 & 0.06 & 2.91 & 1.95 \\
\hline & 0 & 0 & & & & & & 0.02 & & \\
\hline otal & 9.2 & 98.6 & 100.2 & 100 & 99.7 & 99.2 & 100 & 99.30 & 100.3 & 99.8 \\
\hline
\end{tabular}

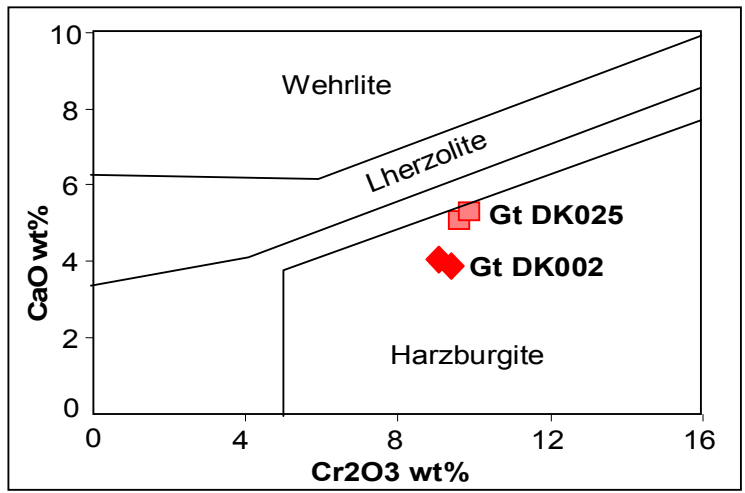

Fig. 4. $\mathrm{Cr} 2 \mathrm{O} 3-\mathrm{CaO}$ plot for Kalimantan garnet inclusions in diamond

\section{Dating}

$\mathrm{Re} / \mathrm{Os}$ dating of the high $\mathrm{Ni}$ sulphide inclusion from South Kalimantan diamond DK15 gave a high Os content and low Re abundance typical of peridotitic sulfides (Pearson \& Shirey, 1999). The single inclusion obviously does not allow the isochron approach. The calculated Re-Os model age is Archean - 3.1Ga +/- 0.2 (2 sigma). Model ages on single inclusions are not robust ages but permit this inclusion and its host diamond to be Archean in age. At the very least, the unradiogenic Os isotope ratio of the sulfide clearly indicates a likely Archean age for the lithospheric mantle hosting the diamond and hence is strongly supportive of derivation of some population of the diamonds from a classical cratonic environment.

\section{Conclusions}

In summary, external morphology, internal structure, $\mathrm{N}$-aggregation characteristics and paragenesis of Kalimantan stones resemble those from kimberlite or lamproite diamonds. The mixed populations of stones in each Kalimantan region, combined with brown radiation spots, minor abrasion features, and lack of poor quality, broken stones, suggests re-working of diamonds from multiple primary sources via a formerly buried sedimentary palaeocollector.

The source of Kalimantan diamonds includes both peridotitic and eclogitic mantle rocks, with the first predominating. Peridotitic mantle rocks are represented by both harzburgites and lherzolites, with one stone yielding an Archean age. Eclogitic diamonds were derived from bimineralic clinopyroxene-garnet eclogite or from kyanite and coesite varieties. P-T calculations for Kalimantan diamond DK15 are consistent with a paleo-heat flow of some $40 \mathrm{mWm}^{-2}$, i.e. subcontinental mantle lithosphere conditions similar to diamonds from African and Yakutian cratonic situations. This suggests that a fragment of ancient continental lithosphere may be preserved at depth within this tectonically complex, arc-type collisional terrain. A diamondiferous ancient lithospheric mantle source could have been obducted to surface, then eroded to release diamonds and covered by later Cretaceous sediments. However, an example of this is Beni Boussera in Morocco (Pearson et al., 1989) where the former diamonds have became completely graphitised during the slow obduction process. For fast transport to surface and preservation of commercialsized diamonds, it is easier to envisage buried, preCretaceous kimberlites bringing the diamonds up from the mantle in classical, eruptive fashion.

\section{References}

Brey, G.P. \& Koehler, T. (1990). Geothermobarometry in four-phase lherzolites II. New thermobarometers, and practical assessment of existing thermobarometers. Journal of Petrology 31, 1353-1378.

O'Neill, H.St.C., and Wall V.J (1987) The olivineorthopyroxene-spinel oxygen geobarometer, the nickel precipitation curve, and the oxygen fugacity of the earth's upper mantle. Journal of Petrology, 28:1169-1191

Parkinson, C.D., Miyazaki, K., Wakita, K., Barber, A.J., and Carswell, D.A., 1998. An overview and tectonic synthesis of the pre-Tertiary very-high-pressure metamorphic and associated rocks of Java, Sulawesi and Kalimantan, Indonesia. The Island Arc, 7, 184-200.

Pearson, D.G., Davies, G.R., Nixon, P.H. \& Milledge, H.J., 1989 Graphitized diamonds from a peridotite massif in Morocco and implications for anomalous diamond occurrences. Nature, Vol. 338, 2nd March 1989, pp. 6062.

Pearson, D.G., Shirey, S.B., 1999. Isotopic dating of diamonds. In Applications of radiogenic isotopes to ore deposit research, Eds.: J Ruiz \& D.D Lambert, Economic Geology Special Publication: SEG reviews in Economic Geology, vol. 9, 143-171.

Vance, E.R., Harris, J.W., and Milledge, H.J., 1973. Possible origins of a-damage in diamonds from kimberlite and alluvial sources. Mineralogical Magazine, Vol. 39, No. 303, pp. 349-360.

Webster, R., 1983. Gems, their sources, descriptions and identification. $4^{\text {th }}$ Edition, Butterworths, London. 